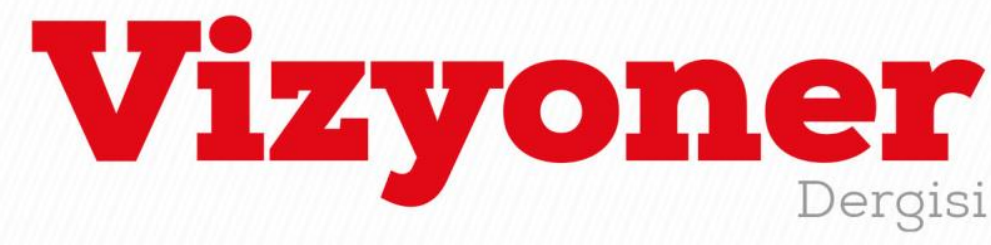

Süleyman Demirel Üniversitesi Vizyoner Dergisi, Yıl: 2022, Cilt: 13, Sayı: 33, 340-353.

Süleyman Demirel University Visionary Journal, Year: 2022, Volume: 13, No: 33, 340-353.

\title{
CHALLANGE OF THE METROPOLITAN GOVERNANCES WITH PANDEMIC DISTRIBUTION: THE CASES OF NEW YORK, LONDON AND ISTANBUL
}

\section{METROPOL YÖNETIMLERIN PANDEMİ ILE MÜCADELESİ: NEW YORK, LONDRA VE İSTANBUL ÖRNEKLERI}

\author{
Assoc. Prof. Dr. Rüveyda KIZILBOĞA ÖZASLAN ${ }^{1}$ \\ Res. Asst. Burak KAPLAN ${ }^{2}$
}

\begin{abstract}
In the study, the struggle of the city administrations of New York, London and Istanbul against the Covid-19 pandemic is examined. Due to their leading status in terms of the number of cases, New York, London and Istanbul are selected as samples. Again, the economic and political capacities of these urban administrations have an important aspect in terms of combating the pandemic. Considering these qualities, the comparison of these urban administrations, which have the capacity to combat the pandemic, is thought to be significant. The aim of the study is to examine the measures taken by the cities and the services they offer comparatively and to offer suggestions for this. Within the scope of the study, conceptual explanations about health, disease and pandemic is made at first and the applications of the metropolitan city governances of different countries are mentioned. In the study, the literature review and the reports prepared by national and international governmental institutions and organizations and non-governmental organizations are used as methods. As a result of the study, the measures taken by the cities are classified under health, economy and social categories.
\end{abstract}

Keywords: Pandemic, COVID-19, Health, Urban, Urban Management.

JEL Classification Codes: H75, I18.

ÖZ

Bu çalışmada New York, Londra ve İstanbul kent yönetimlerinin Covid-19 küresel salgınına karşı verdiği mücadele ele alınacaktır. New York, Londra ve İstanbul örnekelerinin seçilmesinde bu şehirlerde görülen vaka sayılarının ülke genelindeki vakaların öncüsü olmaları öne çıkmıştır. Yine bu kent yönetimlerinin ekonomik ve siyasal anlamdaki kapasiteleri de salgın ile mücadele açısından önemli bir boyuta sahiptir. Bu nitelikler göz önüne alındığında salgın ile mücadele kapasitesine sahip olan bu kent yönetimlerinin karşılaştırılması anlamlı bulunmuştur. Çalışmada şehirlerin aldıkları tedbirler ve vatandaşlarına sundukları hizmetlerin karşılaştırmalı olarak incelenmesi ve öneriler getirilmesi amaçlanmaktadır. Çalışma kapsamında öncelikli olarak sağlık, hastalık ve küresel salgın ile ilgili kavramsal açıklamalar yapılmış ve ardından farklı ülkelerdeki metropol kent yönetimlerinin uygulamalarına değinilmiştir. Çalışmada yöntem olarak literatür taraması ile ulusal ve uluslararası kurum ve kuruluşlar tarafından hazırlanan raporlardan yararlanılmıştır. Öte yandan ele alınan kent yönetimlerinin salgınla mücadele kamuoyu ile paylaştığı resmi belgeler ve web siteleri analiz edilmiştir. Çalışma neticesinde kentlerin aldığı önlemler sağlık, ekonomi ve sosyal olarak sınıflandırılmıştır.

Anahtar Kelimeler: Salgın, COVID-19, Sağlık, Kent, Kent Yönetimi.

JEL Sinıflandırma Kodları: H75, I18.

(D) Marmara University, Faculty of Political Sciences, Department of Local Administrations, ruveyda.kizilboga@gmail.com

2 (D) Beykent University, Faculty of Economic and Administrative Sciences, Department of Political Science and Public Administration, burakkaplan@beykent.edu.tr

Makale Geliş Tarihi / Received : : 21.02.2021

Makale Kabul Tarihi / Accepted : 04.12.2022 


\section{GENIȘLETILMIȘ ÖZET}

\section{Amaç ve Kapsam:}

Bu çalışma Covid-19 salgınının kentleri etkisi altına almasından hareketle hazırlanmıştır. Özellikle nüfus miktarı ve yoğunluğu yüksek olan kentlerin salgın için daha riskli sonuçlar doğurmasına dikkat çekilmiştir. Aynı zamanda yoğun nüfuslu kentlerdeki hareketlilik virüsün yayılmasına uygun koşullar ortaya çıkarmıştır. Dünyanın birçok noktasından farklı sebeplerle gelen turistleri ağırlayan kentlerin de salgınla daha yoğun bir şekilde mücadele etmesi kaçınılmaz olmuştur. Bu kapsamda çalışmada dünyanın önemli kentlerinden olan New York, Londra ve İstanbul kent yönetimlerinin pandemi ile mücadelesi ele alınmıştır. New York, Londra ve İstanbul kent yönetimlerinin pandemi ile mücadelesine kentte yaşayan insanların sağlı hakkının tesis edilmesi kapsamında yaklaşılmıştır. Üstelik kent yaşamı için sağlık hakkının tesis edilmesinin yanı sıra salgının gerekliliği olarak alınan tedbirlerin ekonomik, sosyal ve psikolojik etkilerinin en aza indirilmesinde önerilerin belirlenmesi amaçlanmıştır.

\section{Yöntem:}

Çalışmada yöntem olarak literatür taramasından yararlanılmıştır. Literatür taraması ile hastalık, salgın ve korona virüs gibi temel kavramlar açıklanarak çalışmanın daha anlaşılabilir kılınması sağlanmıştır. Çalışmada aynı zamanda salgının tüm dünyadaki seyrini açıklamak adına nicel verilerden yararlanılmıştır. New York, Londra ve İstanbul kentlerinin salgınla mücadelede attığı adımları tespit etmek adına bu kentlerin yönetimine dair kurumsal internet adresleri incelenmiş ve alınan önlemler tespit edilmiştir. Ayrıca çalışmada ulusal ve uluslararası kurumların hazırladıkları teknik ve analitik raporlardan yararlanılmıştır.

\section{Bulgular:}

Salgınlar insanlık tarihi boyunca belirli dönemlerde toplumları etkisi altına almıştır. Özellikle 20. yüzyıl ciddi sayıda insanı etkileyen salgınların görüldügü bir dönem olmuştur. 20. yüzyılın ilk dönemlerinde ortaya çıkan İspanyol Gribi, 20. yüzyılın ikinci yarısında görülen Asya Gribi ve Hong Kong Gribi bu salgınların en bilinenleridir. 21 yüzyıl ise korona virüs salgınlarının yoğun bir şekilde görülmeye başlandığı bir dönem olmuştur. İlk defa Güney Çin bölgesinde 2002-2003 yıllarında "Sars-CoV" salgını; ardından 2012-2013 yıllarında "Mers-CoV" salgını takip etmiştir. Yaşanan her iki salgının etkileri de küresel ölçekte olmamıştır. Buna karşılık 2019 yılının son günlerinde ilk defa Çin'in Wuhan kentinde görülen yeni tip korona virüs kısa sürede tüm dünyada etkisini göstermiştir. Gerek toplumsal gerekse ekonomik yaşamda derin etkiler bırakan yeni tip korona virüs 11 Mart 2020 tarihinde Dünya Sağlık Örgütü tarafından küresel salgın olarak ilan edilmiştir. Dünya Sağlık Örgütü'nün küresel salgın ilanından sonra yaşanan sosyal hayat kısıtlamaları bir yönüyle toplum sağlığını korumayı amaçlarken bir başka yönüyle de ekonomik hayatta durgunluk ve psikolojik bunalım gibi etkilere yol açmıştır. Özellikle salgının daha derinden hissedildiği metropollerde gerekli tedbirleri alarak salgınla mücadele etmek adına önemli adımlar atılmıştır. Bunları toplum sağlığını ve ekonomik sistemi korumaya yönelik önlemler olarak sınıflandırmak mümkündür. Toplum sağlığı ile ilgili önlemlerde kent yönetimleri salgının enfekte olma hızının yavaşlatılmasına yönelik tedbirler alınmasına odaklanmıştır. Ekonomik önlemler arasında ise kent yönetimlerinin birbirlerinden farklı araçlar geliştirdiği görülmektedir. Yine de ekonomik önlemlerin salgın tedbirlerinin beraberinde getirdiği iş kaybı ve gelir azalmasının etkilerini azaltmayı amaçladığını belirtmek gerekir. Sosyal önlemler ise salgın sürecinde hem dezavantajlı grupların desteklenmesini hem de toplum sağlığının korunmasını amaçlamıştır.

\section{Sonuç ve Tartıșma:}

Önceden tahmin edilmeyen ve aniden ortaya çıkan Covid-19 salgını yerel yönetimler için yeni bir mücadele alanı açmıştır. Bu mücadelede kent yönetimlerinin salgının politik, ekonomik, sosyal ve çevresel etkisi yüksek riskleri düşünerek salgın sürecini planlamalarının gerekliliği anlaşılmıştır. Bunun için ise kentin mevcut durumunun kapsamlı bir analizi yapılması gerekmektedir. Böylece halkın ihtiyaçlarını ve önceliklerini belirlemek, halkın yönetim süreçlerine katılımını teşvik etmek ve iş birliklerini geliştirmek öncelikli konuların başında yer almalıdır. Üstelik tüm bu süreç sağlık hakkı ile ilişkilendirilmelidir. Nitekim kent yönetimleri sağlı hakkının tesisini iç mevzuatlarının en üst belgelerini ve uluslararası sözleşmeleri dikkate alarak planlamalıdır. Kent yönetimlerinin sağlık ve sosyal alanda alacağı tedbirlerin yanı sıra merkezi yönetimlerin ekonomik olarak bu duruma hazır olmaları ve güçlü bir ekonomik yapıya sahip olmaları gereklidir. Nitekim bu süreçte yoksulluk ve işsizlik tüm dünyada daha derinden hissedilen sorunlar arasında sıralanabilir. Bu yüzden yaşanabilecek sosyal sorunları önlemek adına yerel yönetimlerin bütçelerinde öngörülmeyen giderlerin oluşması ve gelir kayıplarının yaşanması söz konusu olacaktır Elbette bu süreci her kent yönetimi ekonomik alanda yerel dinamikleri harekete geçirerek yönetmeyi tercih edebilir. Yerel dinamiklerin harekete geçirilmesi kent yönetimlerinin hizmet alımlarında yerel kaynaklarını kullanmasını, kendi sınırlarında yaşayan şirketlerden ve vatandaşlardan yararlanmasını kapsamaktadır. Ayrıca kent yönetimleri kamuoyunu bilinçlendirmeye yönelik adımlar atmalıdır. Bu kapsamda bireysel önlemlerin sosyal açıdan önemli olduğunun vurgulanması gerekir. Toplumsal yaşamın her alanını etkileyen bu salgında kent yönetimleri sağlık hakkının korunmasında toplumun sağlıklı bir çevrede yaşamını devam ettirebilmesine özen göstermelidir. Bununla beraber sağlık hakkının tesisi için alınan tedbirlerin oluşturduğu olumsuz sonuçların engellenmesi için adımlar atılmalıdır. Aslında bu süreç kent yönetimleri için yeni bir mücadele alanı olarak ortaya çıkmış ve kent yönetimlerinin hizmet öncelikleri ile yatırımlarını gözden geçirmesini zorunlu kılmıştır. 


\section{INTRODUCTION}

Epidemics that affect the world, are explained by the concept of pandemic. This statement actually contains elements that emphasize the locality dimension of a global epidemic. Along with the globalization process, the situation where the interaction between locality and people gained a new dimension and the rapid and frequent occurrence of human mobility in the world, has been effective on the Covid-19 epidemic's spread very rapidly all over the world. In this still-continuing process, the epidemic was infected by millions of people and killed hundreds of thousands of people. In the face of this situation, life has almost stopped in global cities such as New York, Berlin, London, Paris, Rome, Tokyo and Istanbul. This process creates economic and social pressure especially on metropolitan cities. At the point of minimizing this pressure, it is seen that the central government of each country plays a role as the main actor. On the other hand, municipalities also have important responsibilities in the process.

Since pandemics has affected the behavior in the living spaces since the history of humanity, it has been inevitable for the urban administrators to take measures regarding this process. Especially the individuals' gaining a more mobilized form with globalization has also been a determining factor in the spread of the pandemic. As a matter of fact, as a result of the developments in transportation, information and communication technologies, individuals can easily travel to other parts of the world compared to the past, both as tourists and permanently. Therefore, some cities of the world stand out with certain advantageous aspects for individuals. These cities, which stand out with their economic, social and psychological advantages, are exposed to intense mobility all over the world, whether temporary or permanent. While this mobility prepares the environment for the emergence of an adverse situation in terms of pandemics, it puts these cities under difficult conditions in the fight against the pandemic. For this reason, metropolises, as cities with different structures, have come to the fore as the settlements that are most affected by the pandemic and had to fight the most seriously. In a way, taking the pandemic under control in metropolises also means that the pandemic is more manageable within that country. Because the fight of these cities against the pandemic is a factor that directly affects the rate of spread of the disease in the country. So, the success shown in the fight against the pandemic in the metropolises and the performance of these urban administrations in the fight against the pandemic are at a level that can determine the situation throughout the country. The fact that a significant part of the cases seen in their countries in the fight against the pandemic were seen in these cities, which are the three important metropolises of the world, New York, London and Istanbul, were considered within the scope of this study. However, these settlements were influential in the spread of the pandemic in their countries through contacts with patients and in getting the pandemic out of control.

In this respect, the measures taken by these urban administrations to combat the pandemic were determined by considering the examples of New York, London and Istanbul in this study. The measures taken by these urban administrations are classified and compared under health, economic and social categories. At the same time, examples that urban administrations can take in the fight against the pandemic are listed. While determining the recommendations, the concept of the right to health and the role of urban administrations in the establishment of this right were also taken into consideration. Again, by drawing attention to the relations between the urban administrations and the central administrations in the provision of the right to health, suggestions that can be implemented both locally and nationally were expressed, considering that an inclusive management approach will ensure success in the establishment of this right.

This study consists of two sections. In the first section, conceptual explanations are made to support the clarity of the subject. In the second section, the services of New York, London and Istanbul metropolitan city governances in the Covid-19 process, are categorized and explained in health, financial and social manners. In the result and discussion section, the applications of the three metropolitan city governances were analyzed in a comparative way and, suggestions were made for the things to be done. Especially since central governments alone manage the process throughout the country during the epidemic, it creates a serious workload and it has been determined that empowering Local Governments will contribute to the healthier and successful execution of the process. However, it is a fact that the contribution of city governances is directly proportional to their administrative, financial, legal and technical opportunities. 


\section{CONCEPTUAL FRAMEWORK: HEALTH, DISEASE, INFECTIOUS DISEASE, EPIDEMIC, PANDEMIC}

The words health and disease, are round concepts that are tried to be expressed with different definitions. In the face of the difficulty of defining health, the World Health Organization (WHO) was asked to fulfill this responsibility in 1948. In the "Introduction" section of the WHO Constitution (2006), health is defined as "not only the absence of disease or disability, but a state of complete physical, mental and social well-being" (Smith, 2002, p. 883). The disease is described in The Merriem Webster Dictionary as "corrupt, weakened or unstable condition; physical or mental illness" (Merriam-Webster Dictionary, 2020); In the Oxford Learner's Dictionary, "being physically or mentally ill; a condition that affects humans, animals and plants and often arises from infection" (Oxford Learners Dictionaries, 2020).

Infectious disease is defined as follows according to the 2007 Infectious Diseases Surveillance and Control Principles Regulation: "microorganism or disease caused by its toxic products transmitted by human-to-human through direct contact with an infected person or through indirect means such as exposure to a vector, animal, product or environment, or through the exchange of contaminated liquid" (art. 4 / c). In the regulation, the epidemic was defined as: "More cases than expected in a certain area, among a certain group of people, for a certain period of time or, an epidemiologically linked two or more cases or a single case of newly seen / eliminated or eradicated disease with epidemic potential".

Pandemic is the general name given to epidemic diseases that spread and affect in a wide range of countries or continents around the world (Ministry of Health, General Directorate of Public Health, 2019, p. 10). While the contagiousness reaching a certain level for the announcement of pandemic can be seen sufficient, there are some who argue that the severity of the infection should be taken into consideration. For this reason, pandemic is effective in a wide geography, the high speed and severity of this disease, its immunity, the emergence of something new, its contagiousness and its source of transmission (Morens et al., 2009, p. 1018-1020). There are pandemic types that have left their mark in the history of the world. Among them, the ones that came to the fore in the 21 st century are explained in Table 1 with their features and effects.

Table 1. Pandemics Emerging in the 20th and 21st Century

\begin{tabular}{|c|c|c|c|c|c|c|c|}
\hline & $\begin{array}{l}\text { Spanish } \\
\text { Flu }\end{array}$ & Asian Flu & $\begin{array}{c}\text { Hong } \\
\text { Kong Flu }\end{array}$ & $\begin{array}{r}\text { Influenza Flu } \\
\text { A(H1N1) 2009 } \\
\end{array}$ & Sars-Cov & Mers-Cov & Sars-Cov-2 \\
\hline Year & 1918 & $1957-1958$ & 1968-1969 & $2009-2010$ & $2002-2003$ & 2012 & $2019-2020$ \\
\hline $\begin{array}{l}\text { Emergence } \\
\text { Region }\end{array}$ & Uncertain & $\begin{array}{l}\text { South } \\
\text { China }\end{array}$ & $\begin{array}{l}\text { South } \\
\text { China }\end{array}$ & North America & $\begin{array}{l}\text { South } \\
\text { China }\end{array}$ & $\begin{array}{c}\text { Saudi } \\
\text { Arabia }\end{array}$ & $\begin{array}{l}\text { South } \\
\text { China }\end{array}$ \\
\hline $\begin{array}{l}\text { Influenza A virus } \\
\text { subtype (animal } \\
\text { genetic input / } \\
\text { recombination } \\
\text { event) }\end{array}$ & $\begin{array}{c}\text { H1N1 } \\
\text { (Unknown) }\end{array}$ & $\begin{array}{r}\mathrm{H} 2 \mathrm{~N} 2 \\
\text { (bird) }\end{array}$ & $\begin{array}{l}\mathrm{H} 3 \mathrm{~N} 2 \\
\text { (bird) }\end{array}$ & H1N1 (swine) & $\begin{array}{l}\text { Sars-Cov } \\
\quad \text { (bat) }\end{array}$ & $\begin{array}{l}\text { Mers-Cov } \\
\text { (camel) }\end{array}$ & $\begin{array}{l}\text { Covid-19 } \\
\text { (bat) }\end{array}$ \\
\hline $\begin{array}{l}\text { Basic cases of } \\
\text { reproductive } \\
\text { number }(\mathbf{R 0})\end{array}$ & $1,2-3,0$ & $\sim 1,5$ & $1,3-1,6$ & $1,1-1,8$ & $\sim 3$ & $\sim 1$ & $2.0-2.5$ \\
\hline $\begin{array}{l}\text { Estimated case } \\
\text { fatality rate }\end{array}$ & $\% 2-3$ & $<\% 0,2$ & $<\% 0,2$ & $\% 0,02$ & $\% 10,9$ & $\% 35$ & $\% 5$ \\
\hline $\begin{array}{l}\text { Estimated } \\
\text { mortality } \\
\text { attributed } \\
\text { worldwide } \\
\end{array}$ & $\begin{array}{l}20-50 \\
\text { mil. }\end{array}$ & 1-4 mil. & 1-4 mil. & $\begin{array}{l}100-400 \\
\text { thousand }\end{array}$ & 916 & 791 & $\begin{array}{l}\sim 465 \\
\text { thousand }\end{array}$ \\
\hline $\begin{array}{l}\text { Affected age } \\
\text { groups }\end{array}$ & $\begin{array}{l}\text { Young } \\
\text { adults }\end{array}$ & $\begin{array}{l}\text { All age } \\
\text { groups }\end{array}$ & $\begin{array}{l}\text { All age } \\
\text { groups }\end{array}$ & $\begin{array}{l}\text { Children and } \\
\text { young adults }\end{array}$ & $\begin{array}{c}\text { Especially } \\
\text { people aged } \\
65 \text { and over } \\
\end{array}$ & $\begin{array}{c}\text { Older people } \\
\text { and especially } \\
\text { men } \\
\end{array}$ & $\begin{array}{l}\text { Especially } \\
\text { people aged } \\
65 \text { and over } \\
\end{array}$ \\
\hline
\end{tabular}

Reference: (World Health Organization; Ministry of Health, General Directorate of Public Health, 2019, p. 2; TÜBA, 2020, p. 38-41; Altamimi et al., 2020, p. 2).

Covid-19 has been reported to be transmitted to humans on January 7, 2020, leading to respiratory failure. The virus first appeared on December 31, 2019, in people in the seafood market of 11 million Wuhan city in Hubei province in China. The virus, which is spreading rapidly among people, has caused millions of people to fall ill 
within a short period of time and caused hundreds of thousands of deaths (TÜBA, 2020, p. 40-41). Globally as of 17 August 2021, there have been 207.748.507 confirmed cases of Covid-19, including 4.370.424 deaths, reported to WHO. As of 15 August 2021, a total of 4.462.336.040 vaccine doses have been administered (WHO, 2021).

\section{THE ROLE OF METROPOLITAN GOVERNANCES IN COMBATING PANDEMIC "COVID"}

COVID-19, known as the new type of Corona Virus, was first seen in Wuhan, China. The new type of Corona virus spread rapidly to many people in China and then in Iran and Italy. This Path, followed by the virus, in a way, made the European continent the center of the epidemic while it was the road map drawn by the epidemic. The virus continued to spread exponentially after Italy and spread rapidly in Spain and France. The spread of the virus, including the UK and the United States (USA), has led to the number of infected people reaching millions in a short time. Indeed, when looking at the increase in the total number of cases worldwide, it is possible to see this situation. Three months after the first case occurred on December 31, 2019, the total number of cases exceeded the 1 million line limit. However, the number of reaching 2 million cases from 1 million cases occurred in only 14 days. The time to reach 3 million from 2 million cases decreased to 12 days. As of June 26, 2020, the number of cases worldwide is approaching 10 million (Worldometers, 2020a) (See Figure 1). As the new type of coronavirus pandemic is an ongoing process, the number of Coranavirus cases has exceeded 200 million on a global scale as of August 17, 2021 (WHO, 2021).

Figure 1. Total Number of Cases Seen in the World

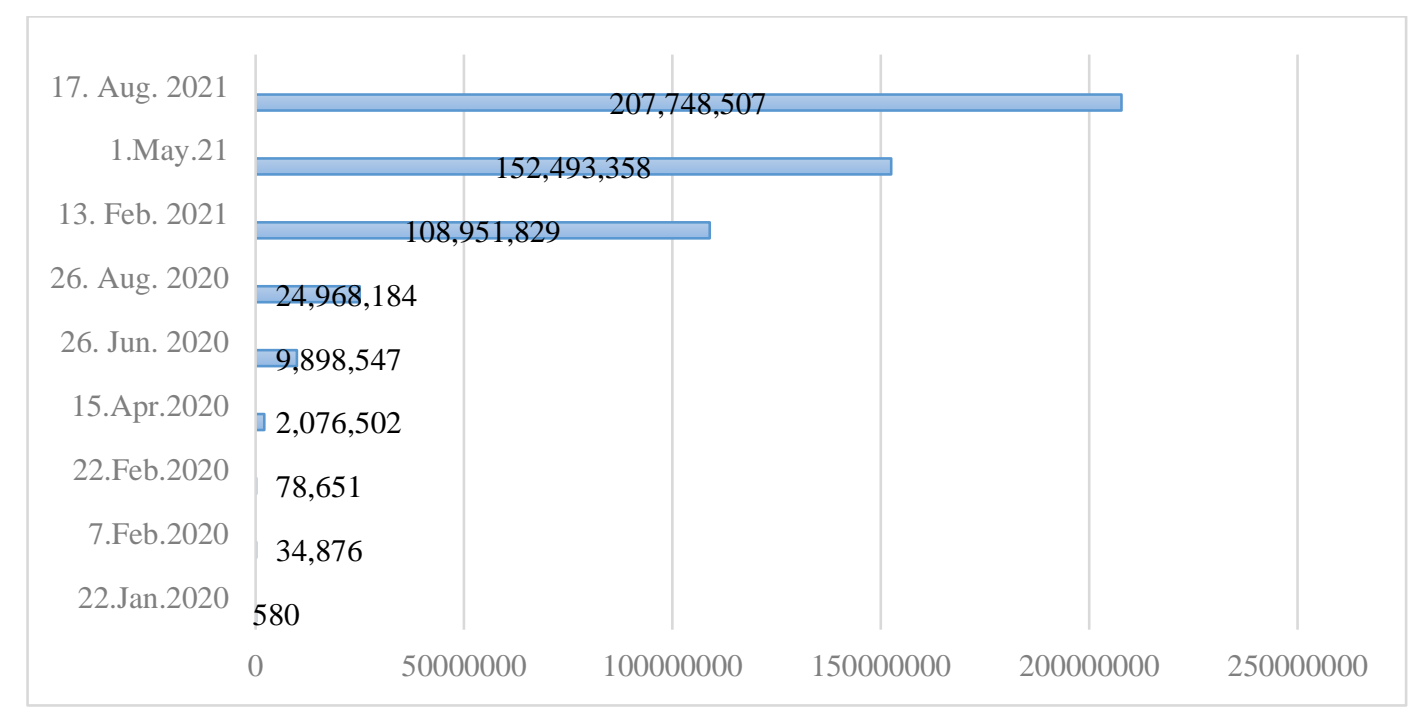

Reference: (Worldometers, 2021a).

Although it was clearly seen that the situation faced threatened all humanity, the epidemic was more effective especially in cities with dense external connections. Indeed, it is possible to say that global cities face relatively more serious threats in this process. The fact that a large number of tourists from many different countries of the world come to these cities, and the fact that these cities are very busy in themselves can be seen among the factors that spread the virus. Therefore, the epidemic processes of metropolitan cities such as New York, London and Istanbul, which are determined in this section of the article, are discussed. While determining these cities, attention was paid to preferring those affected by the epidemic.

There are three main reasons for comparing the examples of New York, London and Istanbul. Firstly, New York, London and Istanbul are at the center of pandemic in themselves country. Secondly, these cities have significant economic capacity. Thirdly, New York, London and Istanbul are within the borders of countries in different political systems. In United States, There is federal system and In United Kingdom and Turkey, there are unitary systems. Therefore, these differences have imposed responsibilities to local governments. In the other words, these local governments have struggled with the pandemic within their responsibilities in accordance with their own legal conditions. Because of these reasons these cities have been selected to comparison. 
Süleyman Demirel Üniversitesi Vizyoner Dergisi, Yıl: 2022, Cilt: 13, Sayı: 33, 340-353.

Süleyman Demirel University Visionary Journal, Year: 2022, Volume: 13, No: 33, 340-353.

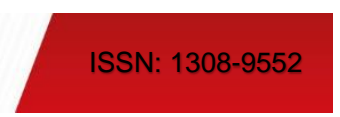

\subsection{New York Case}

The case of COVID-19 in the USA was first seen on January 21, 2020 (Centers for Disease Control and Prevention, 2020). After the first case was detected, it was late at the point of taking serious and strict measures in the USA. At this point, it is possible to say that the federal government belittled the epidemic. As a result of taking measures late, the number of cases across the country increased rapidly. As stated above, while the total number of cases seen in the country on March 12 was 1,630, this number reached 13,898 a week later on March 19. On April 1, 200,000 border lines were exceeded in the number of cases in the country. A full month after this date, that is, on May 1, the number of cases in the country became more than 1 million. On 17 August, the total number of cases in the country was $37,896,582$. Thus, nearly a quarter of the total cases in the world became visible in the USA. When the total number of cases in the world reached 209,594,114 as of Aug 17, 37,896,582 of these cases were seen in the USA (Worldometers, 2021b).

When looking at the general distribution of the cases within the country, it is possible to say that the densely populated states of the country are much more affected by the epidemic. Nearly $40 \%$ of cases in the country occurred in the states of New York and New Jersey. New York, in particular, is the state where the situation is most critical in the country. Because almost $1 / 3$ of the number of cases and deaths in the country were seen in this state (Health New York, 2020). After the new type of corona virus epidemic spread in New York, the state government has come to the point of taking its own measures. Considering that each state is a federated state due to the political system of the USA, it can be said that the freedoms of these state governments may be wider in terms of policy making compared to other countries. Therefore, this may suggest that the relations between federated states and the federal state have become important in the epidemic process. However, it is necessary to consider the impact of the New York City Council together with the federated state. In this context, addressing the Local Government systems and duties, powers and responsibilities of the countries in relation to the city government may contribute to explaining the status of the city governments in a healthier way during the pandemic process. If you need to look at the differentiating structure of local governments in New York, there are 62 districts throughout the state, including New York City. There are local government units in the province, including provincial, district and village administrations. These local government units are empowered by the federal government on many issues such as social security, public order, infrastructure and economic development (Department of State New York, 2020).

It is seen that the services that local governments are responsible for providing are evaluated in two scopes. The first of these is the services required for daily life to continue. It is possible to list these services as nutrition, shelter and medical care. Others are presented in a general framework to organize entertainment and cultural activities and to coordinate with the state administration while performing public services in order to make the city attractive. However, it is possible to say that the services provided by Local Governments are classified under nine headings. These are; State Department Operations; Social Work and Public Health Programs; Social Development; Public Safety, Environmental Protection; Transportation; Consumer Protection Services; Employees and Working Conditions and Other Services "(A Division of the New York State Department, 2018, p. 163). When these service areas offered by the local governments are analyzed in the context of the Covid-19 epidemic, it is possible to say that there are important responsibilities in combating the pandemic. As a matter of fact, it is seen as the first noticeable service area that Local Governments are also held responsible for public health. However, it is possible to say that the service areas such as working conditions, transportation, public safety and consumer protection are also affected by the epidemic process.

During the epidemic, the New York City government first introduced developments related to the epidemic into digital media. In this way, the number of sick and dead in the state is followed; it is seen in which region of the province the patients are located and their demographic characteristics and disease histories can be reached. (Health New York, 2020). In addition to sharing the data, measures such as the social distance rule, masking, and staying at home unless it is compulsory are now shared on the state government website. However, in case of symptoms related to the disease, measures to be taken by citizens are also explained and free diagnostic tests have been carried out (City of New York, 2020a). Areas such as parks, picnic areas and entertainment centers are closed. It has been decided to perform possible services with online methods (City of New York, 2020b). With these measures taken to prevent the spread of the epidemic, it can be seen that the city governments aimed to overcome the social and economic problems caused by the epidemic. In this context, it was announced that inclusive updates were made regarding social rights, food, housing and unemployment. 
In these regulations, it is seen that reaching all segments of the society is one of the primary agenda items. In this context, a precautionary approach was adopted that prioritizes children, immigrants, the elderly and the disabled. In the field of employment, applications were received to make retrospective payments through unemployment insurance for those who lost their jobs due to the epidemic. It has been announced that citizens will be supported on food aid. Addresses through which Geographic Information Systems (GIS) can meet the nutritional needs of those in need are shared on the internet (City of New York, 2020c). In this period, leaseholders, tenants, were forbidden to leave the house by force, and financial support was announced for housing, stating that this action was illegal. Another situation related to housing was the disclosure of utility bills for electricity and heating. In education, it is stated that students will be supported for distance education tools. It has been explained that psychological support will be given to people whose mental health is affected during the epidemic process (City of New York, 2020d). It is possible to say that two approaches are dominant when the measures taken in New York. The first is to prevent the spread of the current epidemic. The second was about those who were socially and economically affected by the epidemic. In this context, it has been seen that economic and social measures are explained, especially for disadvantaged groups and those who lose their income or work with low wages.

\subsection{London Case}

In the UK, the case of COVID-19 was first detected on January 31, 2020. With the determination of the first case and WHO declared an emergency on January 30, some measures were taken across the country. Despite these measures, the virus spread rapidly throughout the country after March, and the UK has become one of the countries with the epidemic. While the total number of cases in the country was 23 at the end of February, this number increased to 383 on March 10. On 20 March, the total case was recorded as 3.983. In April and May, the virus continued to spread rapidly in the country. As of August 17, 2021, the total number of cases in the country has reached 6,322,241 (Worldometers, 2021b).

It is possible to say that the central government's approach to combating the epidemic is also effective in the rapid spread of the epidemic in the country. This approach, which is defined as herd immunity, is considered as one of the methods that can be applied in the fight against epidemics in the literature. While the groups that the virus can affect are primarily protected, those without health problems are expected to continue their lives (Kwok, Lai, Wan In Wei and Tang, 2020, p. 1). However, serious criticism has been raised regarding the use of this method in the UK. More than 200 scientists from different fields from genetics to mathematics in the country have warned the government about this strategy and urged the government to take serious measures (BBC, 2020).

The calls put forward gave a late result and, even if strict measures were taken in the UK, it became the third country with the highest number of deaths worldwide on 26 June (Worldometers, 2020b). The effects of the virus deeply affected important city centers in the country, bringing life to a standstill, as in most parts of the world. London, the capital of the country, is considered as one of the cities that are significantly affected by the epidemic. As a matter of fact, almost 1/3 of the epidemic deaths in England occurred in London (London Government, 2020a). In this context, the harmonization of the central government and the city government in the fight against this situation faced by London may contribute to both controlling the epidemic and minimizing its economic and social effects.

The areas served by the City of London are listed as public order and crime prevention, health, transportation, firefighting, environment, housing, economy, education and youth, art and culture, planning, employment, research and sports (London Government, 2020b). In the process, the City of London called people to stay at home and stated that they should use a mask if they go out. It has been announced that those who show symptoms of disease should not visit the parks and it is announced that collective activities will not be allowed in public places. The metropolitan police announced that they could leave the houses only in four cases. These situations are; daily food and medication needs, Individual walking and cycling, medical necessity and going to work for those who do not have jobs suitable for working from home (London Government, 2020c). It is possible to consider these measures as measures taken to protect the social distance and to slow down the spread of the virus. It is also necessary to look at the measures taken to alleviate the social and economic effects of the epidemic.

In this context, the City of London has created a donation platform to support small businesses. Cash inflows were provided to small businesses during this period (Pay it Forward, 2020). By establishing food banks, it was aimed that disadvantaged groups such as the elderly, disabled and immigrants could access food products. The system has also been opened to support citizens with their donations (London Government, 2020d). For those who have 
lost their income due to the epidemic, the ways to follow are also determined. In this context, it is stated that the employees will benefit from a measure package according to their status. Employment status is divided into three as employees, workers and self-employed. It is stated that the broadest supports are reserved for employees. While it is stated that employees have more limited rights, self-employed people have the least rights in this context. It is stated that those who lost their jobs or income due to the epidemic will be paid up to $80 \%$ of their salaries or up to $£ 2500$ (Citizen Advice, 2020). In addition, the Mayor of London called on the government to take steps to prevent the leaseholders from discharging the tenants from the house and to support those who cannot pay their rent through the social security system (London Government, 2020e).

The City of London has made several attempts to compensate for the socio-economic impacts of the epidemic process as well as the disruptions in the field of education. In this context, it has prepared a platform where educational and cultural documents prepared for students of different age groups can be accessed through digital media. In addition, a support program for mental protection of young children has been announced (London Government, 2020f). Looking at the measures taken by the City of London in the epidemic process, it is seen that the aim is to slow down the speed of virus spread. Social solidarity was pointed out in reducing the economic and social effects of the epidemic. In addition, financial support and rental assistance were provided to those who suffered a loss of income through social security services. Due to the unitary nature of the country, it is possible to say that the freedoms of city governments are limited. Because of this, city governments aimed to manage the process in harmony and cooperation with the central government because they could not respond to many issues within their own capacity.

\subsection{Istanbul Case}

The new type of coronavirus cases were found on March 10, 2020 for the first time in Turkey. With the first case, serious measures were put in place by the government, such as the closure of schools. Despite the measures taken, it has not prevented the virus from spreading in Turkey. Indeed, on 1 April 2020, 20 days after the first case occurred, the number of cases reached 15,676. The total number of cases increased to 122,392 on May 1. As of May 10, the total number of cases has reached 138,657. As of August 17, 2021, the total number in the country has reached 5,704,713 (Republic of Turkey Ministry of Health Covid-19 Information Platform, 2021).

The occurrence of a positive momentum in the number of cases healed, is an important issue for Turkey. As of June 26, 2020, the number of active cases declined to 22,248. The resulting cases, on the other hand, resulted in 5,065 deaths and 167,198 recovery (Republic of Turkey Ministry of Health Covid-19 Information Platform, 2020). In Turkey, the reasons for the positive momentum in the recovery rate in case of arrest, were measures taken since the first day the virus was detected. In this context, in Turkey, a source of disease, serious and firm measures against the people of contamination have been taken. For the source, practices such as finding the source of the disease, reporting the disease, making a definitive diagnosis, ensuring the treatment and isolation of the patient, searching for carriers and providing health education are carried out. For the contamination, environmental conditions, personal cleaning, provision of protective equipment and restriction of population mobility have been provided. Quarantine and observation measures were taken for healthy people (TÜBA, 2020, p. 44-45).

Before the epidemic was seen in this country, if we look at the measures taken by Turkey, after 13 days from the date of 11.01.2020 as seen from the first death in China, conducted flights between Wuhan and Istanbul were stopped on 24.01.2020. As of 04.02.2020, passengers from countries where the epidemic occurred were controlled by thermal cameras at the airports. All flights from China were stopped on 05.02.2020. Following the epidemic seen in Iran, on 02/23/2020, Iran-Turkey land border gates were closed. After the epidemic occurred in Italy, South Korea and Iraq, round-trip passenger flights with these countries were stopped. After the first case was seen, schools were closed on 12.03.2020. On 13.03.2020, restrictions were made in public events. On 15.03.2020, it was decided to introduce comprehensive travel and transportation restrictions and to close places where people gathered together. On the same date, the last group from Umrah visit was placed in student dormitories. On the date of 16.03.2020, Friday and time prayers in the country were interrupted in the mosque. On 17.03.2020, flights with 20 countries were closed. Football, basketball, volleyball and handball leagues were stopped on 19.03.2020. On 21.03.2020, the number of countries closed to flight rose to 68. On 22.03.2020, it was decided to go flexible working in public. On 24.03.2020, the capacity of public transportation vehicles was reduced to $50 \%$. On 28.03.2020 intercity bus-plane trips were subject to permission, and flights abroad were closed. Since April, the lackdown started on the weekends. Lackdowns were extended up to three or four days if coincided with official 
holidays. On 06.05.2020, it was declared by the Minister of Health that the first period ended in the fight against global epidemics (TÜBA, 2020, p. 45-47).

Despite all the measures taken in Turkey, the general spread of the epidemic in the country, could not be prevented. Metropolitan cities, especially Istanbul, were more heavily affected by this process. Even if there is no explanation about the distribution of cases to cities, the implementation of lockdowns in 30 metropolitan cities and Zonguldak also supports this argument. Especially Istanbul is the center of the epidemic in the country. As a matter of fact, Health Minister Fahrettin Koca confirmed at the press conference on April 29, 2020 that 60\% of the cases were seen in Istanbul (Istanbul Metropolitan Municipality Covid-19 Scientific Advisory Council, 2020, p. 7). It is possible to say that the structure of the city is decisive for Istanbul to face such a situation. Indeed, Istanbul is the most populous city in the country with a population of over 16 million. On the other hand, coexistence of this population provides a suitable environment for the spread of the virus. This problem faced by Istanbul required the city government to take serious measures against the epidemic.

In this context, Istanbul Metropolitan Municipality (IMM) announced that it focused on social assistance and solidarity efforts during the epidemic. He implemented practices such as providing food support to families with babies, providing cash assistance to private public bus tradesmen whose income was significantly affected during the epidemic, producing mask and protective equipment, not demanding rent from their tenants, and delivering food and cash aid to families without income. (Istanbul Metropolitan Municipality Covid-19 Platform, 2020). In addition to these activities, IMM also launched a charity campaign called "pending bill" by including citizens in the process. Thus, an online platform is offered for citizens who want to help those in need (Istanbul Metropolitan Municipality Pending Bill, 2020).

When the practices of IMM in the epidemic process are considered, it is seen that it focuses on social aid and solidarity. It is possible to say that both in-kind and cash aids are provided for those who lose their income or jobs, and that they support the businesses and tradesmen affected by the process to the extent of the metropolitan municipality's capacity. It is also possible to address the following issue for IMM. In this process, it is possible to comment that the conflict is dominant rather than cooperation between the city government and the central government.

As a matter of fact, Istanbul Metropolitan Municipality Mayor İmamoğlu called the Ministry of Health in order to detect Covid-19 contacts and drew attention to the fact that no data about patients was shared with them (Cumhuriyet, 2021). In addition, the IMM administration, considering that the number of deaths and cases announced by the Ministry of Health does not reflect the truth, started to share the number of people who died due to infectious diseases in Istanbul on a daily basis and drew attention to the fact that these data do not match the figures announced by the Ministry of Health (BBC, 2021). As a result, this conflict between the urban administration and the government has revealed a disadvantageous situation in the effective management of the social distance rules implemented in the early stages of the pandemic.

\section{RESULT AND RECOMMENDATIONS}

In a process where people can cross borders easily and quickly, their accompanying illness has left humanity and states at one of the costs of being a global world. This can be easily explained by the Covid-19 epidemic, which brought the world to some extent in 2020. The first question that comes to mind is how prepared are both humanity and the states for this cost and what they plan to survive with the least damage. The problem concerns both humanity and the states, but states are expected to be the first addressee to be expected to answer both trouble and question. It should also be noted that the central governments' determination to manage the process has seen the accelerating and facilitating effect of empowering Local Governments in the process.

In this context, the practices of New York, London and Istanbul city governments are included in the study. First of all, it is seen that, in terms of the relations of the city governments with the central government, New York and Istanbul are conflict-oriented rather than cooperation, and in London, harmony is dominant in cooperation point. The works of the city governments, which are explained in detail under the heading "Measures Taken by the City Governments", are compiled in Table 2. In this process, city governments took measures in terms of rent payments of both households and workplaces. In New York, the state government has announced that it will support those who cannot afford to pay its rent, and that the ban on removal will be implemented. In London, the city government 
called on the central government to grant lease assistance. In the case of Istanbul, the city government has announced that its own workplaces rent payments are delayed.

In this process, it is seen that the city governments have implemented certain measures for those who have lost their jobs or income. In New York and Istanbul examples, cash and in-kind assistance are available, while in London the city government has taken a consultancy role for citizens to benefit from the resources provided by the central government. In terms of social solidarity, it is possible to come across positive examples in Istanbul and London. However, it is not seen that the city government has a clear initiative in this aspect in New York. As a matter of fact, citizens intensified their aid even more with the effect of Ramadan in Istanbul. However, participation in the "pending bill" aid campaign organized by the municipality supports this claim. In the case of London, citizens supported small businesses by pre-sales and ordering.

In this process, disadvantaged groups were also on the agenda of city governments. The city governments have identified disadvantaged groups as the elderly, the disabled, children, immigrants and those who are not registered in the social security system. Another issue is what kind of steps the city governments took in the field of education. As a matter of fact, the epidemic process has also affected the education-training process significantly. At this point, the New York City government has announced that it will provide equipment for students in need during the distance education process. London, on the other hand, introduced an online platform for students to access the necessary resources. In Istanbul, the city government stated that a distance test will be held in order to support students in preparing for high school and university exams. In Table 2 below, the measures taken by the mentioned city governments during the epidemic are presented in general terms.

Table 2. Measures Taken by City Governments

\begin{tabular}{|c|c|c|c|}
\hline & New York & London & Istanbul \\
\hline $\begin{array}{l}\text { Health } \\
\text { Measures }\end{array}$ & $\begin{array}{l}\text { - Free diagnostic tests } \\
\text { - Sharing of epidemic data in digital } \\
\text { media in detail } \\
\text { - Sharing for the protection of } \\
\text { mental health }\end{array}$ & $\begin{array}{l}\text { - Preparation of guide for } \\
\text { diagnostic test } \\
\text { - Publishing guidelines for the } \\
\text { protection of mental health }\end{array}$ & $\begin{array}{l}\text { - Mask distribution } \\
\text { - Disinfection of public spaces }\end{array}$ \\
\hline $\begin{array}{l}\text { Economic } \\
\text { Measures }\end{array}$ & $\begin{array}{l}\text { - Financial support for those who } \\
\text { lost their jobs or income } \\
\text { - Rental assistance, prohibition of } \\
\text { removal from the house } \\
\text { - Sharing the locations where the } \\
\text { needy people in the city can meet } \\
\text { their nutritional needs with GIS } \\
\text { - Establishment of a job application } \\
\text { platform for those who lost their } \\
\text { jobs during the epidemic period }\end{array}$ & $\begin{array}{l}\text { - Counseling for those who } \\
\text { lost their jobs or income in } \\
\text { order to benefit from } \\
\text { government funds } \\
\text { - Call to the central } \\
\text { government for rent support, } \\
\text { prohibition of house } \\
\text { removal }\end{array}$ & $\begin{array}{l}\text { - Supports in kind to those who lost } \\
\text { their jobs or income } \\
\text { - Postponing the rent payments of } \\
\text { the municipal establishments }\end{array}$ \\
\hline $\begin{array}{l}\text { Social } \\
\text { Measures }\end{array}$ & $\begin{array}{l}\text { - Efforts to disadvantaged groups } \\
\text { - Publication of guides explaining } \\
\text { social relations in the new normal } \\
\text { order }\end{array}$ & $\begin{array}{l}\text { - Efforts to disadvantaged } \\
\text { groups } \\
\text { - Volunteering and donation } \\
\text { mechanisms }\end{array}$ & $\begin{array}{l}\text { - Efforts to disadvantaged groups } \\
\text { - Suspended bill application } \\
\text { - Creating motivation by making } \\
\text { cultural and artistic activities } \\
\text { accessible during the quarantine } \\
\text { period }\end{array}$ \\
\hline
\end{tabular}

When looking at the management efforts of the cities during the epidemic process, it is possible to see different results due to the unique conditions of each country. For example, when we look at the level of decentralization of health spending by OECD countries, the report shows that the United States achieves a higher health spending compared to the city government in England and Turkey. The share of urban management in community public health spending in the United States, while more than $40 \%$, this ratio is below $15 \%$ in the UK and Turkey. It is possible to interpret this situation as a result of the federal structure of the USA. In addition, the process led to a significant decline in the financial resources of city governments and spending a significant part of their budgets in the fields of health and social recovery. According to preliminary data obtained from 46 states in the USA, there was a $49 \%$ decrease in total state tax, $63 \%$ in personal tax income, $15.8 \%$ in sales taxes and $63 \%$ in corporate tax compared to April of the previous year. For the UK, the expenses of the Local Governments are expected to decrease significantly as a result of the financial pressures that come with Covid-19. As a result of this pressure 
faced by the budget, city governments are entering into a troubled process in supporting people in distress. Due to the mentioned loss of income, investments in service areas such as public security, parks and recreation areas and infrastructure may be disrupted (OECD, 2020).

Increasing urbanization rates with the globalization of the economy and technological developments radically change the environment and living conditions in which people live (Takano, 2004, p. 1). According to UN data, $55 \%$ of the world population lives in urban areas as of 2018. While this rate is $30 \%$ in $1950,68 \%$ of the world's population is expected to live in cities in 2050 (United Nations Department of Economic and Social Affairs, 2018, p. xix). When this increase is taken into consideration, it is likely that the problems related to the establishment and protection of health, as in many areas, especially in developed and developing countries, will be possible in the next process if necessary measures are not taken. It is likely that WHO, taking this situation into account, developed the Healthy Cities Project thirty-three years ago, in 1987, and implemented it in eleven pilot cities (WHO European Regional Office, 1997, p. 12). The project is a long-term international development work aimed at putting health on the agenda of decision-makers and promoting comprehensive local strategies for health. Its main features include social participation and empowerment, cross-sectoral cooperation and participant equality. The main goal was to enable city governments to make decisions by taking into account health issues in their social, economic and political priorities. It is emphasized that all institutions such as education, culture, environment, industry, social etc. should be included in the working areas, but Local Governments should play a leading role in protecting and improving public health and welfare (Boulos \& Shorbaji, 2014, p. 3). When the right proportion is established, it can be evaluated that healthy cities can be the guarantee of healthy individuals.

The healthy city, on the other hand, is a city that is conscious of health and its improvement rather than the city that has reached a certain health position. The healthy city is the city that constantly improves the physical and social environment and develops social resources that enable people to fulfill all the functions they need and mutually support each other to reach their maximum potential (World Health Organization Regional Office for Europe, 2020). The purpose of healthy cities is to create an environment that supports health, to achieve a good quality of life, to meet the needs of cleaning and hygiene, and to provide access to health services (World Health Organization, 2020).

The following can be suggested for the metropolitan administrations that take the first degree in the construction of healthy cities to achieve a successful result from their pandemic and trials:

- Local governments, who are caught unprepared for this difficult process, should plan the next process through political, economic, social and environmental policies, taking into account the risks that are unlikely to occur, but are high in effect if they arise. In the process of turning the policies into plan, the following are required; to conduct comprehensive analyzes on the current situation of the city, to determine the needs of the people, to determine the priorities and to encourage the participation of the people in these processes, to authorize local administrators in order to benefit from the positive effects of cooperation and to follow-up and evaluate the process.

- Cities should be planned taking into account the provisions in the Constitution and the international conventions to which the right to health is associated with the environment.

- In addition to the measures to be taken by the city administrators in the health and social fields, the states should be prepared for this situation economically. In this process, besides the disease, unemployment and poverty emerged as another cost area. For example, taking measures for rational determination and efficient use of the unpredictable expenses appropriation in the budgets of the municipalities and the allowance allocated for the poor and needy at the disposal of the mayor may be a supportive example to overcome such financial difficulties.

- Property tax, penalty and interest payments can be delayed or extended.

- Economic support can be provided through pre-sales and orders to workplaces that remain closed during the epidemic period and whose revenues have decreased substantially.

- Municipalities may prefer local citizens for their jobs such as maintenance, repair and service procurement. For example, services such as maintenance and repair of educational institutions within its borders can be performed by people living in that area and working in these areas. Transporters living in the region can benefit from some products distributed to the public. 
- Measures should be taken to raise public awareness. Particularly, taking into consideration the possible disasters that may occur in the future, trainings that can be prepared for these processes can be given from childhood. It is necessary to gain the awareness that individual measures are socially important.

- Solidarity and cooperation with non-governmental organizations can be increased.

- Measures should be taken to protect women and children who have been subjected to violence during the period when lockdown is applied, in order to protect the needs of the disabled and their families, especially to support their socialization.

- For homeless people and people living on the streets, kiosks can be placed in the central locations of the city showing the points where they can meet their needs such as shelter, nutrition and dressing. Those who live in the city and have the opportunity to help those in need can also share their data here.

- Municipalities can be used to perform diagnostic tests, which is an important factor in preventing the spread of the virus. In particular, mobile health committees can collect the diagnoses for testing in Panel van type vehicles under suitable conditions.

- The periods when lockdown is applied can be evaluated with infrastructure, road maintenance, playgrounds, park and garden works and repairs, which are more difficult to build in normal times.

- In order to support access to cheap food, mobile sales vehicles can travel around the city under the coordination of municipalities.

- With the voluntary participation of people who are engaged in arts and sports among the citizens of the town, online concerts, crafts and painting courses, play hours for children, and sports activities that can be done at home can be organized on the municipality website.

- Solidarity mechanisms can be developed by taking into consideration the grievances that students, whose education and training process continues with online tools, can experience. With suitable distance conditions, places where the internet, computer and printer can be accessed and hygienic conditions are provided can be created.

- Applications for the online presentation of many services such as marriage can be implemented.

- Giving importance to the works supporting the spirit of unity and togetherness that will ensure social solidarity will also contribute to the overcoming of the process, especially with less psychological damage.

- Municipalities can use this success as an opportunity to strengthen their public relations in electoral districts when they manage the crisis well.

- Distance work practices and e-municipal services can be expanded in municipalities.

- Municipalities can provide health trust label approval for businesses and shops in the new normal order.

- In the epidemic of cities, the city administrators can play a role in balancing the demand for reverse migration and preventing qualified human resources from moving away from the city.

- Municipalities may apply different tariffs at certain time intervals in order to spread the density in public transportation. In addition, different transportation alternatives can be brought to the agenda in cities where city transportation is possible by sea.

- New forms of dialogue can be developed to increase public participation through digital technologies.

- With the smart city systems, the resistance of the cities can be increased during the epidemic.

- As a result of the cooperation between the Ministry of Health and Municipalities, the health conditions of the people with QR Code can be inspected in public areas in order to reduce the risk of citizens' mobility in the city. For example, people who have to remain in quarantine as a result of these scans at the shopping malls and store entrances or get close to someone infected with the virus may be kept in their home for control purposes.

\section{DECLARATION OF THE AUTHORS}

Declaration of Contribution Rate: The authors have equal contributions.

Declaration of Support and Thanksgiving: No support is taken from any institution or organisation.

Declaration of Conflict: There is no potential conflict of interest in the study. 
Süleyman Demirel Üniversitesi Vizyoner Dergisi, Yıl: 2022, Cilt: 13, Sayı: 33, 340-353.

Süleyman Demirel University Visionary Journal, Year: 2022, Volume: 13, No: 33, 340-353.

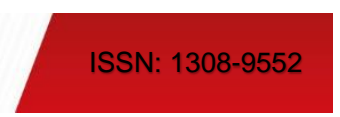

\section{REFERENCES}

A Division of the New York State Department of State. (2018). Local government handbook. New York State.

Altamimi, A., Abu-Saris, R., El-Metwally, A., Alaifan, T., \& Alamiri, A. (2020). Demographic variations of MERS-CoV infection among suspected and confirmed cases: An epidemiological analysis of laboratorybased data from riyadh regional laboratory. BioMed Research International, (2020), 1-6.

BBC. (2020). Coronavirus: Some scientists say UK virus strategy is 'risking lives'. Retrieved May 10, 2020 from https://www.bbc.com/news/science-environment-51892402

BBC. (2021). Coronavirus: Minister of Health Koca called Imamoğlu after the criticism of 'You are late in taking precautions' and said, 'We are working with precision'. Retrieved August 18, 2021 from https://www.bbc.com/turkce/haberler-dunya-54928522

Boulos, M. N. K., \& Shorbaji, N. M. (2014). On the internet of things, smart cities and the WHO healthy cities. International Journal of Health Geographic, 13(10), 1-6.

Centers for Disease Control and Prevention. (2020). First Travel - related Case of 2019 Coronavirus Detected in United States. Retrieved April 28, 2020 from https://www.cdc.gov/media/releases/2020/p0121-novelcoronavirus-travel-case.html

Citizen Advice. (2020) Coronavirus - being furloughed if you can't work. Retrieved May 10, 2020 from https://www.citizensadvice.org.uk/work/coronavirus-being-furloughed-if-you-cant-work/

City of New York. (2020a). Coronavirus (COVID-19) updates. Retrieved May 11, 2020 from https://access.nyc.gov/coronavirus-covid-19-updates/\#section-4

City of New York. (2020b). New York City agency servise updates. Retrieved May 11, 2020 from https://www1.nyc.gov/nyc-resources/city-agency-service-updates.page

City of New York. (2020c). Get Food NYC. Retrieved June 25, 2020 from https://dsny.maps.arcgis.com/apps/webappviewer/index.html?id=35901167a9d84fb0a2e0672d344f176f

City of New York. (2020d). Retrieved May 11, 2020 from https://www1.nyc.gov/site/doh/covid/covid-19-main.page

Cumhuriyet. (2021). Ekrem Imamoğlu's call to closure of Istanbul. Retrieved August 18, 2021 from https://www.cumhuriyet.com.tr/haber/ekrem-imamoglundan-istanbul-icin-kapanma-cagrisi-1790966

Health New York. (2020). Retrieved May 1, 2020 from https://covid19tracker.health.ny.gov/views/NYSCOVID19-Tracker/NYSDOHCOVID-19Tracker-Map?\%3Aembed=yes \&\%3Atoolbar=no\&\%3Atabs=n

Infectious Diseases Surveillance and Control Principles Regulation. (2007). Official Gazette No. 26537. dated 30.05.2007.

Istanbul Metropolitan Municipality Covid-19 Platform. (2020). Retrieved May 10, 2020 from https://koronavirus.ibb.istanbul/ibb-sorumluluk/

Istanbul Metropolitan Municipality Pending Bill. (2020). Retrieved May 10, 2020 from https://askidafa0tura.ibb.gov.tr/Invoice-List

Kwok, K. O., Lai, F., Wan In Wei, S. Y., \& Tang, J. W. (2020). Herd immunity - estimating the level required to halt the COVID-19 epidemics in affected countries. The Journal of Infection, 6(80), 1-2.

London Government. (2020a). Coronavirus (COVID-19) Deaths. Retrieved May 10, 2020 from https://data.london.gov.uk/dataset/coronavirus--covid-19--deaths

London Government. (2020b). What we do. Retrieved May 10, 2020 from https://www.london.gov.uk

London Government. (2020c). Coronavirus (COVID-19): Supporting food banks. Retrieved May 10, 2020 from https://www.london.gov.uk/coronavirus/volunteer-and-donate/coronavirus-covid-19-supporting-foodbanks

London Government. (2020d). Pay it forward. Retrieved May 10, 2020 from https://payitforward.london.gov.uk

London Government. (2020e). Rights of renters and landlords during coronavirus. Retrieved May 10, 2020 from https://www.london.gov.uk/coronavirus/rights-renters-and-landlords-during-coronavirus 
Süleyman Demirel Üniversitesi Vizyoner Dergisi, Yıl: 2022, Cilt: 13, Sayı: 33, 340-353.

Süleyman Demirel University Visionary Journal, Year: 2022, Volume: 13, No: 33, 340-353.

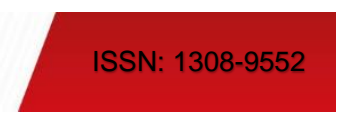

London Government. (2020f). Educatfion and childcare. Retrieved May 10, 2020 from https://www.london.gov.uk/coronavirus/education-and-childcare

Merriam - Webster Dictionary. (2020). Retrieved April 9, 2020 from https://www.merriam-webster.com

Ministry of Health, General Directorate of Public Health. (2019). Pandemic Influenza National Preparedness Plan, Retrieved April 8, 2020 from https://www.grip.gov.tr/depo/saglikcalisanlari/ulusal_pandemi_plani.pdf

Morens, D. M., Folkers, G. K., \& Fauci, A. S. (2009). What is a pandemic. The Journal of Infectious Diseases, 200, 1018-1021.

New York State. (2020). Department of State, Division of Local Government Services. Retrieved May 9, 2020 from https://www.dos.ny.gov/lg/localgovs.html

OECD. (2020). The territorial impact of COVID-19: Managing the crisis across levels of government. Retrieved June 25, 2020 from http://www.oecd.org/coronavirus/policy-responses/the-territorial-impact-of-covid19-managing-the-crisis-across-levels-of-government-d3e $314 \mathrm{e} 1 /$

Oxford Learner's Dictionaries. (2020). Retrieved April 9, 2020 from https://www.oxfordlearnersdictionaries.com

Republic of Turkey Ministry of Health Covid-19 Information Platform. (2021). Daily case numbers. Retrieved August 18, 2021 from https://covid19.saglik.gov.tr/

Smith, R. (2002). In search of 'non-disease. British Journal of General Practice, 324(7342), 883-885.

Takano, T. (2004). Development of healthy cities and need for research. In T. Takehito (Ed.), Healthy cities \& urban policy research (p. 1-9). Taylor \&Francis e-Library.

TÜBA. (2020). Covid-19 global epidemic evaluation report. Turkish Academy of Sciences.

United Nations Department of Economic and Social Affairs. (2018). World urbanization prospects the 2018 revision. Retrieved June 23, 2020 from https://population.un.org/wup/Publications/Files/WUP2018-Report.pdf

World Health Organization [WHO]. (2006). Constution. Retrieved April 7, 2020 from https://www.who.int/governance/eb/who_constitution_en.pdf

World Health Organization [WHO]. (2020). Types of healthy settings. Retrieved June 25, 2020 from https://www.who.int/healthy_settings/types/cities/en/

World Health Organization [WHO]. (2021). WHO Coronavirus (Covid-19) Dashboard. Retrieved August 18, 2021 from https://covid19.who.int/

World Health Organization Regional Office for Europe. (1997). Twenty steps for developing a healthy cities project, 3rd Edition, Retrieved April $15, \quad 2020$ from http://www.euro.who.int/_data/assets/pdf_file/0011/101009/E56270.pdf?ua=1

World Health Organization Regional Office for Europe. (2020). What is a health city? Retrieved June 25, 2020 from https://www.euro.who.int/en/health-topics/environment-and-health/urban-health/who-europeanhealthy-cities-network/what-is-a-healthy-city

Worldometers. (2020a). Coronavirus cases. Retrieved June 27, 2020 from https://www.worldometers.info/coronavirus/\#countries

Worldometers. (2020b). Total cases. Retrieved June $27, \quad 2020 \quad$ from https://www.worldometers.info/coronavirus/worldwide-graphs/\#total-cases

Worldometers. (2021a). Total cases in UK. Retrieved August 18, 2021 from https://www.worldometers.info/coronavirus/country/uk/

Worldometers. (2021b). Acitve cases in the United States. Retrieved August 18, 2021 from https://www.worldometers.info/coronavirus/country/us/ 